\title{
Gender Gaps in the Clouds: Expressive Repression and Signs of Change in Italian Comics of the 1950s and 1960s
}

\begin{abstract}
This article focuses on the change to the gender gap in the history of Italian comics as a sign of social change in Italy. The article makes a brief reference to the US, which serves as an important basis for comparison with the impositions from above that comics production had to suffer in Italy; then focuses on the first clear signs of gender-role changes in the comics scene nationwide, starting in the early 1960s; and ends by noting the sexual liberation expressed in comics in the second half of the 1960s.
\end{abstract}

Keywords: Auteur comics, black comics, censorship, comics, Comics Code, comics history, crime comics, Fascism, fumetti, Garanzia Morale, gender, graphic narrative, Italian K-factor, sex comics, sexual liberation

\section{The original sins of Italian comics}

The history of fumetti (comics) in Italy has been that of a long, ongoing process of social acceptance as a narrative medium with the same status as other media. Throughout the last century, generations of parents and educators perpetuated the belief that it was mostly a pastime to blame, a distraction from more formative readings. The pictorial constituent as central to the narrative process was poorly tolerated initially. It is no coincidence that the original Italian comics resembled a Bildergeschichte (picture story) by Wilhelm Busch rather than a comic. Considered as the true vehicle of the stories' educational value, written text could only be presented in the form of captions (balloons were forbidden as they were regarded as anti-educational), as with the adventures of Bilbolbul (the first Italian comics character), published in the Corriere dei Piccoli starting on 27 January 1908, which consisted of a sequence of drawings accompanied by rhyming verses. US comics, published in the same magazines, were modified into a similar format, text balloons eliminated partially for technical reproduction purposes, but mostly for cultural reasons (see fig. 1).

The cultural intolerance of comics in Italy was particularly clear in the second half of the Fascist period. Clinging to the glorious past of Italian literature, official cultural institutions imposed that the drawings in comics be instrumental and 


\section{CORPIERE deI PICCOLI

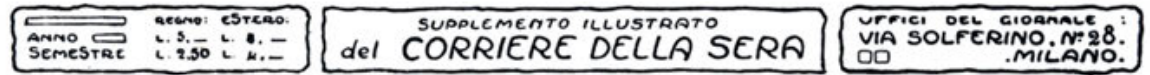

Anno 1. - N. 1. 27 Dicembre $1908 . \quad$ Cent. 10 il numero.
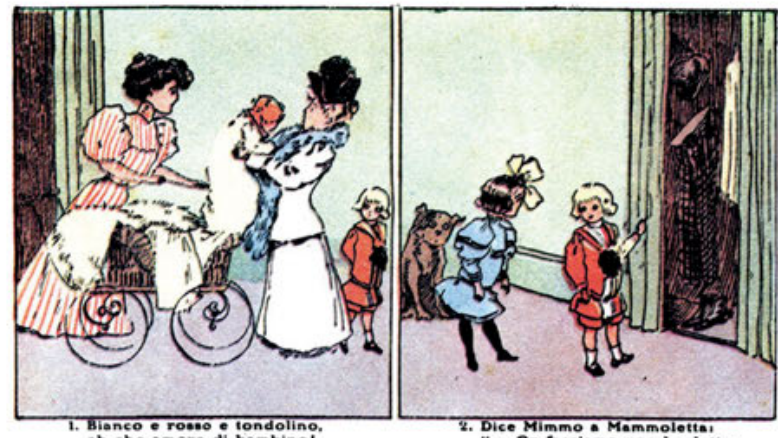

che amore di bembinot

2. Dice Mimmo a Mammolettal
-- Or facciamo una burlette.
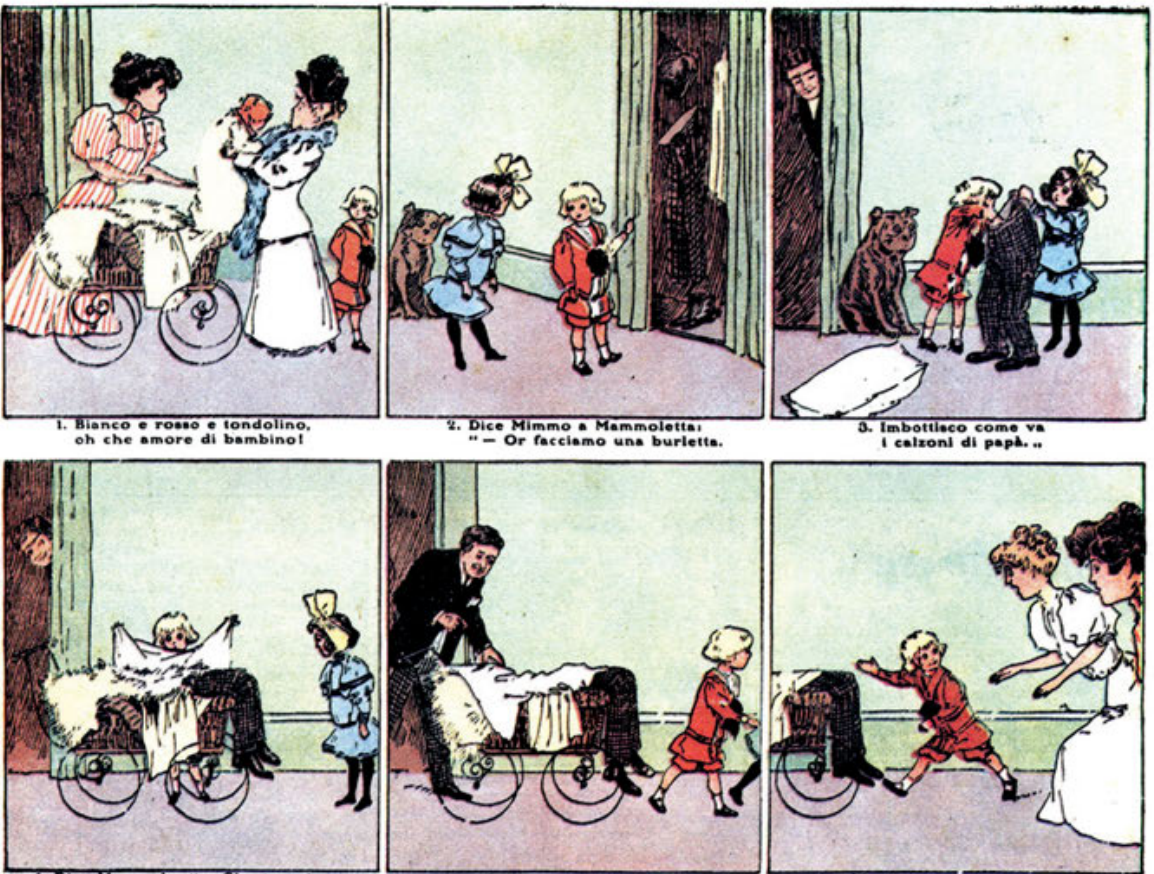

calxonl di papt. ..

Par che in cune ci oid un womo:

5. Ma 11 papd ch'ers nascosto
del fantoceio prende il posto
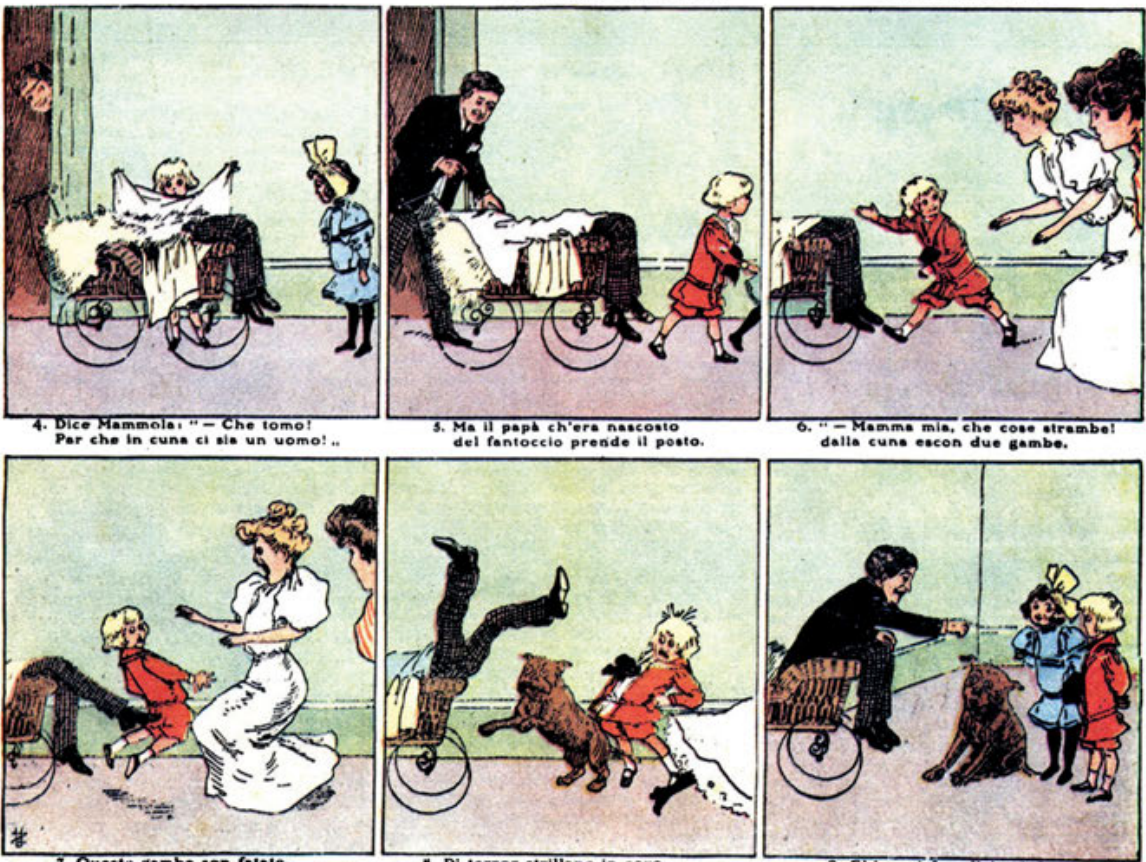

dalle cuns eacen due gambe.

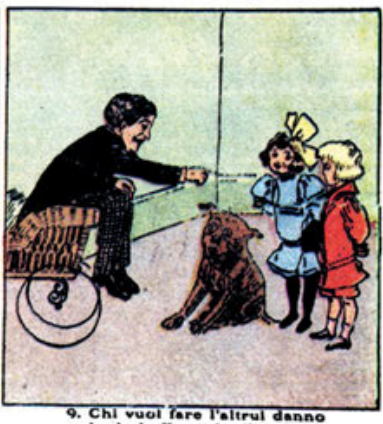

7. Oueote Eambe con fatste,

D. Di terror otrillono in coro
Mimmo, Mammole. Medoro.

ha te beffe ed ha 11 malsano.

Fig. 1: Cover page of Corriere dei Piccoli 1 (27 December 1908). ( ) Rizzoli. 
subordinate to the text. Even as US adventure comics were becoming popular in the country, the Mussolini regime issued directives aimed at avoiding the spread of models that contrasted with its ideology. As proof of comics' power to influence popular opinion, the importing of foreign works and the use of balloons were forbidden (Guzzetta 2009, 16-18).

The independent model of American womanhood was one reason for concern. Figures coming to the fore and endorsing the values of a consumer society, such women undermined the accepted roles for Italian women: wife, mother, and worker in the service of national glory. Characters like Petronilla (the Italian Maggie, the female protagonist of Bringing Up Father by George McManus), ironically depicted as the typical "social climber, who strives to be fashionable and to attend high society, flaunting elegant moves and stylish hats" (Guzzetta 2009, 28; my translation), represented deviance from Italian social structure. In such a context, it is no wonder that comics heroes were men and women supported them (Guzzetta 2009, 27-31).

Things did not change much after the war. The major obstacle to the creativity of writers and artists remained conservative political power and religious cultural environments, which guaranteed the continued status quo of gender roles in printed publications, and open hostility when the authors attempted to renegotiate traditional gender roles. By the 1950s and 1960s, comics in Italy faced a campaign of hatred and impositions from above, similar to what resulted in the US Comics Code.

\section{Censorship and reaction: A look at the case of US comics}

In August 1949, the detonation of the first Soviet atomic bomb marked the end of the US monopoly on strategic nuclear armaments. Afterward, a wave of anti-Communist hysteria, fomented by Senator Joseph McCarthy, created a climate of profound civil and ideological instability in the US across all social strata. By the time President Eisenhower intervened, ending the senator's career, McCarthy had bequeathed a fierce and uncompromising conservatism to US society.

In this period, comics had already been criticized by Gershon Legman, who found a glorification of violence that he linked to the denigration of sexuality in US culture (Legman 1963 [1949]). Legman's criticism had had no significant effect on the publishing market, but, in the new climate of insecurity, Seduction of the Innocent by the psychiatrist Fredric Wertham (1954) triggered a wave of fierce 
censorial moralism against comics. Wertham attributed much deviance, such as juvenile delinquency and sexual perversions, to comics.

Emblematically, Wertham detected an ambiguous relationship between the adult Batman and the young Robin. Wertham described Robin as "a handsome ephebic boy, usually shown in his uniform with bare legs. He is buoyant with energy and devoted to nothing on earth or in interplanetary space as much as to Bruce Wayne. He often stands with his legs spread, the genital region discreetly evident" $(1954,191)$. At the expense of every female figure, Robin occupied the heart of his friend Bruce Wayne and often behaved intimately with him. The stories of the "Dynamic Duo" were regarded, in this view, as manifestly homosexual and anti-feminist. Nevertheless, Wertham found "the Lesbian counterpart of Batman" $(1954,192)$ in the stories of Wonder Woman and Black Cat, arguing that Wonder Woman gave a wrong idea of femininity to her readers (233-235).

Associations of parents and teachers railed vehemently against many comics publications. The Subcommittee of the US Senate on Juvenile Delinquency could not censor comic books without violating the First Amendment of the US Constitution, which guarantees freedom of speech and the press. To avoid government interference, comic-book publishers, similarly to the film industry with the Production Code, took matters into their own hands. In 1954, the Comics Magazine Association of America (CMAA) adopted the Comics Code ("Code of the Comics Magazine Association of America, Inc." n.d. [1954]), strict guidelines to be applied by the Comics Code Authority. All printed material had to pass the scrutiny of the Authority, and approved works were marked with a special seal (see fig. 2).

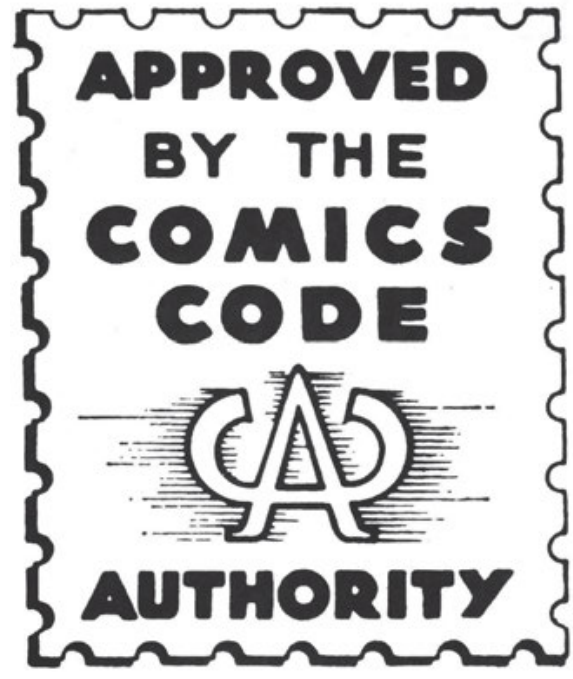

Fig. 2: Seal of the Comics Code Authority. 
Although the Comics Code did not have legal value, retailers often refused to distribute publications without the CCA's seal of approval. More than any other cultural product, comics were choked by rigid self-censorship which forbade violence, crime and its means, sexuality and its deviant forms. No criticism of established authority, or religion, or marriage was allowed; romantic relationships were canonical; the heroes were men; and even the strongest women played supporting roles. The code served to legitimize widespread prejudices, reaffirm socially accepted gender roles, and compel writers and artists to create morally and graphically simple stories, making comics into a youth product.

In the 1960s, the Comics Code came into question. A new generation of authors created an underground culture and began to circulate stories in flagrant violation of the Code, which took the name "comix." Initially produced by individual artists and sold on the street, comix ridiculed established authority, playing with its phobias; promoted alternative social models; praised sexual freedom; and rebelled against the mortification of the female figure and homophobia. This trend started alternative modes of publishing. Later versions of the Code became gradually less restrictive (see Wolk 2011) until the Comics Code Authority ceased to exist in January 2011.

\section{Moral control of Italian comics}

While McCarthyism was raging in the US, Italy was in the midst of its post-war centrist period. Here too, comics had no easy life, forced into expressive stasis by a censorship supported by intellectuals and educators. In the early 1950s, a series of publications promoted an image of comics as an inferior phenomenon, an obstacle to a smooth educational process, or even a cause for degradation. One striking case was Pantera Bionda, the adventures of a female Tarzan in Malaysia (first published 1948), written by Giangiacomo Dalmasso and drawn by Enzo Magni (alias Ingam; see fig. 3). The first sexy heroine of Italian comics was greeted initially with resounding success, a smear media campaign, and a shower of protests and letters of denunciation by official cultural institutions and envious rival publishers. Eventually, in part because of the judicial authority's repeated interventions, the publisher Pasquale Giurleo was forced to dress the protagonist, who had appeared in a leopard-print bikini, in a blouse and a long skirt that would lead to the demise of the publication. ${ }^{1}$

1 At the end of the 1930s, a similar fate had befallen Betty Boop by Max Fleischer in the US. 


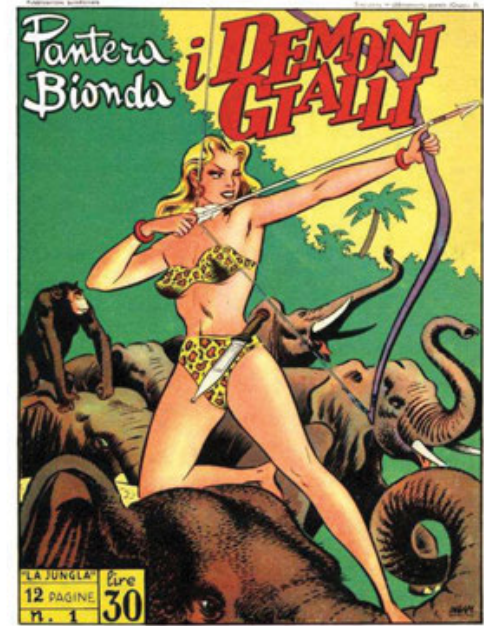

Fig. 3: Cover of Pantera Bionda 1 (24 April 1948). (c) Enzo Magni, Giangiacomo Dalmasso.

In 1951, two members of parliament, the Christian Democrats Maria Federici Agamben and Giovanni Battista Migliori, with the support of other party members, presented a draft law to establish preventive control over comics publications (Federici Agamben et al. n.d. [1949]). The Bill was not approved by the Senate, but similar initiatives were revived in 1955 and 1958, without success (Savio et al. n.d. [1955]; Savio and Manzini n.d. [1958]). As in the US, publishers acted, and in April 1961, a self-monitoring body was established within the Associazione Italiana Editori Periodici per Ragazzi (Italian Association of Publishers of Periodicals for Young). This body, the Unione Italiana della Stampa Periodica Educativa per Ragazzi (Italian Union of the Educational Periodical Press for the Young), or UISPER, ${ }^{2}$ was constituted by the Catholic component of the Association and self-appointed as the evaluator of nationwide comic production. Based on a specially crafted moral code, UISPER determined which publications were good and worthy of bearing the "Garanzia Morale" [Moral Guarantee] seal on their cover (see fig. 4).

A message inside the early publications explained that these comics did not harm the moral and intellectual education of young people. It certified that a work was in line with the dominant values of society and lacked violent scenes, foul or obscene language, or depictions of inappropriate poses, attitudes, and clothing, particularly for women. Reprints of old comics were subject to retouch-

2 Curiously, this acronym's Italian pronunciation might sound like a reference to a voice of conscience. 


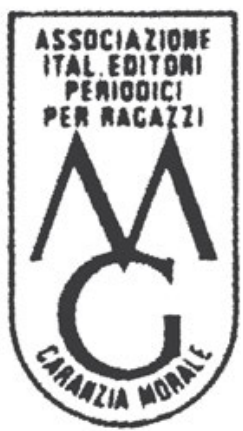

Fig. 4: Seal of Garanzia Morale.

ing to remedy various necklines or hints of nudity judged indecent by UISPER. For example, female characters in the adventures of Tex Willer, the most famous character of popular Italian comics, were retouched to maintain the new moral standards, as in the first strip of Il capitano della River's Queen (cf. the original version, published in Tex 16 [13 January 1949] and as published in later editions, in Detti [1984, 83] and Borsotti [n.d.]).

\section{A criminal revolution: The season of "black" comics}

In the early 1960s, the Milanese sisters Angela and Luciana Giussani prompted a revolution in the Italian comics scene. In 1962, Angela founded the publishing house Astorina, and on 1 November, Diabolik 1, "Il Re del Terrore" [The King of Terror], first appeared on newsstands (see fig. 5). Its subtitle, "Il fumetto del brivido" [The Thrilling Comic], dispelled any lingering doubts as to the nature of this new publication. It was a comic for the adult public, intended to arouse strong emotions during a train ride, as the series intentionally targeted commuters. The pocket-sized format $(12 \times 17 \mathrm{~cm})$ revolutionized the comics scene and allowed readers to store or hide Diabolik with ease. The pocket format characterized all fumetti neri (black [crime] comics), as well as the pornofumetti (porn comics), which would be launched shortly thereafter, encouraging clandestine reading.

Revolution, it was said. Diabolik was a masked hero, but a negative hero, an unrivalled criminal who executed impossible robberies. Therefore, reader acclaim became unacceptable and censors intervened frequently, to the point of the sequestration of issue 82 (1967) on the order of the praetor of Lodi (Raffaelli 2004, 9-10). Parents and teachers forbade Diabolik, and moralists censured adults caught in possession of those books. 


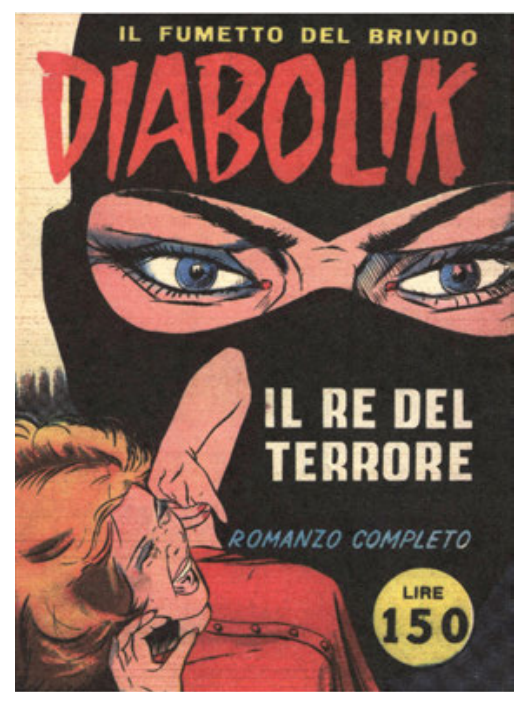

Fig. 5: Cover of Diabolik 1. (c) Astorina.

The pages of Diabolik narrated both the crimes of its protagonist and his fulfilment of a socially imposed civil disobedience. Diabolik's co-protagonist Eva Kant, his life companion and accomplice from the third issue, shared the background of a loveless childhood. Diabolik grew up on an island of criminals indifferent to him; Eva was the illegitimate daughter of the scion of a wealthy and noble family that had prevented the marriage of her humble mother. Eva and Diabolik were united by a sincere, indissoluble affection, fighting against a world without love that only cultivated the value of wealth. Their stories were the instrument through which the authors, as they indicated, pointed out the contradictions of contemporary society, which was an immediate attraction for many new readers, including many women, who traditionally were not the intended target of the genre. The sincere love, sensuality, and equality between Diabolik and Eva critiqued a society that claimed it held high moral principles while denying its own sexist nature.

The founding of Astorina marked the popular rise of works lacking a Moral Guarantee seal, and Diabolik was only the first in a series of antagonistic heroes with exotic-sounding sinister names frequently containing the letter " $k$ " (the genesis of what Italians call the "K-factor"). The market was soon flooded with titles like Fantax, Fantasm, Demoniak, Spettrus, Sadik, Jnfernal, Zakimort, and Genius, featuring criminals in tights following the model of Diabolik, without reaching a qualitatively similar result. The author Igor Tuveri (alias Igort) explained: 


\begin{abstract}
They were mostly masked heroes whose name was dressed with that malignant K. Today, after so many years [...] we wonder if the "K," a traditionally Jewish letter, carried the somewhat racist legacy of a letter of evil; somehow infamous (let us not forget the depth of war propaganda penetration, [which was] such that an entire generation grew up with a sense of mistrust towards the Japanese, a true incarnation of the "yellow danger"). (Tuveri 2001, 8 ; my translation)
\end{abstract}

Compared to the Giussani sisters' prototypical Diabolik, this slew of epigones was characterized by elements of sadism and perversion that produced a fairly wide typology of characters perpetrating socially prohibited behaviours. These characters were often devoid of psychological characterization, and the screenplays were inconsistent. Far from civil protest, these publications fit into a market laid bare by Diabolik, relying on primal human instincts for maximum economic return.

Nevertheless, it should be noted that some valuable works, like Kriminal and Satanik occupied this controversial current (see fig. 6). Published by the publishing house Corno, the two series were created in 1964 by writer Luciano Secchi (alias Max Bunker) and artist Roberto Raviola (alias Magnus), and depicted protagonists who were well characterized and engaged in clearly motivated - not
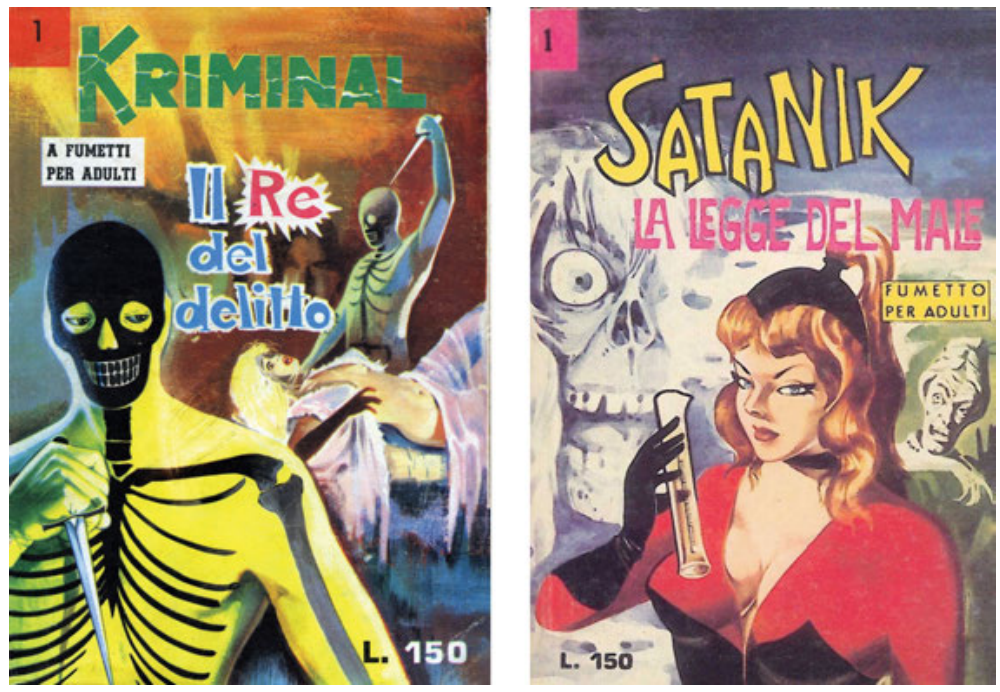

Fig. 6: Covers of Kriminal 1 and Satanik 1. @ Max Bunker used by permission of the author. 
gratuitous - criminal conduct. These series had accurate scripts, crafted, among other things, in order to create continuity within the series. ${ }^{3}$

Like Diabolik, Kriminal and Satanik seek revenge against a society that causes all evil. Anthony Logan is a victim of a tormented childhood, linked to the dark side of a capitalist, bigoted reality, in response to which he becomes Kriminal, "il Re del Crimine" [the King of Crime]. Satanik is the biologist Marnie Bannister, tormented and abused by her two beautiful sisters because her face was disfigured by an angioma. After discovering a beauty serum, Marnie turns into the beautiful, ruthless killer Satanik, "la Rossa del Diavolo" [the Devil's Redhead]. After scarring one sister and killing the other, Satanik pursues a career of murder and lust, motivated by social revenge, the lust for power and money, hatred of women, and contempt of men.

The readers of Kriminal and Satanik, like those of Diabolik, were attracted by the charm of defiance against rules that society imposed to mask its fears and contradictions. Unlike Diabolik, who was faithful and loyal to Eva, Kriminal (before meeting his girlfriend Lola) and Satanik change partners and, in defiance of the national sex-phobia, live their stories to the full in full view of the reader. In addition, Diabolik's adventures were told with traditional, emotionally minimal art that mirrored the humorous yet tense atmosphere of the series. In contrast, Kriminal and Satanik (often with the humour that would distinguish their authors' subsequent output and send the virtuous over the edge) was elevated by Magnus's innovative graphics and modern and ironic style. Thus, Kriminal and Satanik were blacklisted and frequently censored and confiscated. As crime and sadism spread on the Italian newsstands in the 1960s, a veritable witch-hunt instigated by uptight publishing milieus culminated with a press campaign that resulted in the cancellation of several publications and led the authors of others, including Kriminal and Satanik, to moderation.

\section{Comics' sexual liberation}

The expression of sexual liberation was an emerging phenomenon in comics preceding the ' 68 Movement. On the eve of the 1950s, the sexy heroine Pantera Bionda was forced into a premature disappearance from the Italian newsstands,

3 Another interesting fact is the meeting of the two characters in issue 90 of Kriminal, "Quello che non t'aspetti" [What You Don't Expect], published on 16 March 1967. To the best of our knowledge, it is the first recorded case of a crossover in Italian comics. 
and even in the mid-1960s, the pressure of the Catholic press made life tough for the provocative protagonists of the national comics scene. Mafalda, the Argentine artist Joaquin Lavado's (alias Quino) child-protagonist and icon of the time, denounced the hypocrisy and injustices caused by the stupidity of adults. In April 1965, Giovanni Gandini founded Linus, the first Italian comic magazine, which included European comic strips, articles, reviews, and new comics alongside the classic American Syndicated comic strips. The architect Guido Crepas (alias Guido Crepax) made his debut in the second issue with La curva di Lesmo [The Lesmo Curve], the pilot for a series initially starring Neutron, the man with the paralysing gaze, alter ego of the art critic Philip Rembrandt. The photographer Valentina Rosselli began as Neutron's girlfriend, but would soon relegate her partner to the role of supporting character.

The original Italian erotic comic heroine, Valentina was intelligent, curious, open-minded, and lived her romantic adventures without constraints from her partner Philip, with whom she established a free and passionate relationship from the very beginning. References to contemporary reality were continuous: Valentina frequents the bourgeois and intellectual environment of contemporary Milan and, although her adventures are often dreamlike, her actual dreams represent the humours, desires, and human needs of real society. Unlike the canonical protagonists of comic strips, Valentina ages with her author, dealing with changes to her body and experiencing wider psychological development.

At that time, a growing distinction between fumetti popolari (popular comics) and fumetti d'Autore (Auteur comics), and their enthusiasts, began to emerge in Italy. Fumetto d'Autore generally referred to a product of high aesthetic quality that often had the connotation of elite comics, distinguished as an "artwork" comic from a popular product associated with works intended for children and minus habens. The term would characterize comic production in the years to come, and, by the second half of the sixties, seemed to be applicable to erotic comics.

From the beginning, Crepax had what it takes to be an "Auteur." But, for the guardians of morality and the public who shared their sensibilities, such distinctions lacked relevance and could not legitimize undesirable content. Therefore, Valentina's actions soon prompted a placement change for comics stories with any content of a sexual nature. The critic Luca Boschi reported that, in those years, the readers of Linus

proved to be essentially quite conservative and prudish; they did not approve of too many heroines, especially if they were scantily dressed. They protested even when, in 1969, Linus published a reportage on the exuberant Phoebe Zeit-Geist, drawn by the American artist Frank Springer: the few panels in which she was shown naked and bent over on herself, between the columns of the opening article, seemed not really suitable for a publication intended for a broad audience that could therefore fall into children's hands. 


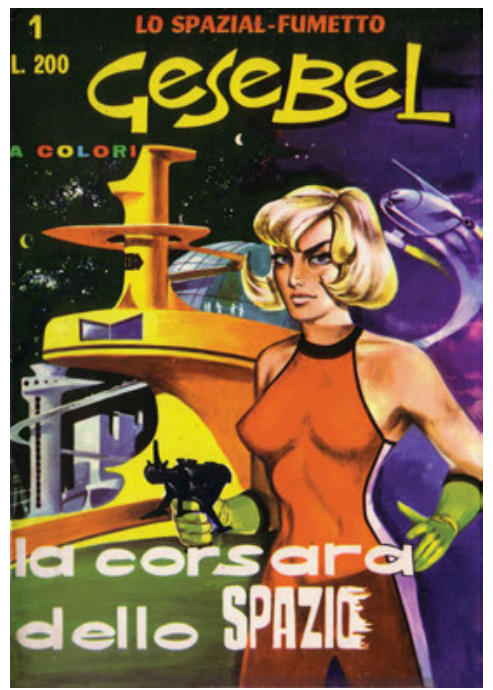

Fig. 7: Cover of Gesebel 1. (C) Max Bunker used by permission of the author.

The victims of this type of evaluation, the female characters likely to arouse in the reader some sinful instinct, or even some rash reaction, would usually be confined to the supplements, capacious containers with a square spine and a print run lower than the monthly magazine. Used as Indian reservations, they welcomed without any problems all materials that shared the following, weak common denominator: they could not be accommodated inside Linus. (Boschi 2007, 68-69; my translation)

Valentina shared this fate with the scantily dressed protagonists of the French comics by Georges Wolinski and Georges Pichard. Similarly, the amorous adventures in space of the beautiful and uninhibited Barbarella by Jean-Claude Forest, published since 1962 in France and proposed for Italy since debuting in Linus in 1967 (remembered for the elimination of the nipples of the protagonist), were relegated to the aperiodic supplements to the magazine.

Of course, the worst attacks targeted popular erotic comics (still labelled "comics for adults" in the 1970s) in various genres. The fantasy-erotic Gesebel (starting in 1966), another Bunker/Magnus creation, provided a setting between science fiction and fantasy for its audacious scenes (see fig. 7). The authors mocked prohibitions of nudity by dressing female characters with transparent clothes. Isabella, written by Giorgio Cavedon and drawn by Sandro Angiolini (also starting in 1966) was characterized by a progressive, although contained, sadomasochistic component. Set in seventeenth-century France, it told the adventures of a beautiful, uninhibited swordswoman seeking revenge, who often became the victim of violence. 
These series continued for several years and were exported despite the interventions of the judicial authority. They combined the profitable erotic component with the image of a strong, independent woman, tired of the limitations of a bigoted bourgeois respectability, who finally managed to take the role of protagonist in a medium that was traditionally the prerogative of male readers and heroes. It seemed that society had not changed much, but fifteen years after her disappearance Pantera Bionda was avenged. ${ }^{4}$

\section{Works cited}

Borsotti, Andrea. “Censure, queste sconosciute.” Tex Willer: Appunti per collezionisti. Ed. Borsotti. n.d. http://www.fantascienza.net/vegetti/Tex/index.htm (26 April 2018).

Boschi, Luca. Irripetibili: Le grandi stagioni del fumetto italiano. Rome: Coniglio Editore, 2007. "Code of the Comics Magazine Association of America, Inc." 1954. cbdlf.org. Comic Book Legal Defense Fund, n.d. http://cbldf.org/the-comics-code-of-1954/ (26 April 2018).

Detti, Ermanno. Il fumetto tra cultura e scuola. Florence: La Nuova Italia, 1984.

Federici Agamben, Maria, Giovanni Battista Migliori, Nicola Angelucci, Attilio Bartole, Oscar Luigi Scalfaro, Raimondo Manzini, et al. "Vigilanza e controllo della stampa destinata all'infanzia e all'adolescenza." 19 December 1949. Camera dei deputati: Portale Storico. Parlamento Italiano, n.d. http://storia.camera.it/documenti/progetti-legge/19491219-995federici-agamben-ed-altri-vigilanza-e (26 April 2018).

Guzzetta, Eleonora. "Sorelle d'Italia: La donna nel fascismo a fumetti." Le donne del fumetto: L'altra metà dei comics italiani: Temi, autrici, personaggi al femminile. Ed. Sara Zanatta. Latina: Tunué, 2009. 11-55.

Legman, Gershon. Love and Death: A Study in Censorship. 1949. New York: Hacker Art Books, 1963.

Piepoli, Angelo. “La Rivoluzione delle nuvole." /l '68 diffuso. Ed. Silvia Casilio and Loredana Guerrieri. Vol. 2. Bologna: CLUEB, 2010. 73-93.

Raffaelli, Luca, “Introduzione.” I classici del fumetto di Repubblica: Serie Oro 4. Rome: Gruppo Editoriale l'Espresso, 2004. 5-12.

Savio, Emanuela, and Raimondo Manzini. "Disposizioni sulla stampa destinata all'infanzia e all'adolescenza.” 13 June 1958. Camera dei deputati: Portale Storico. Parlamento Italiano, n.d. http://storia.camera.it/documenti/progetti-legge/19580613-7-savio-e-manzini-disposizioni-sulla (26 April 2018).

Savio, Emanuela, Elisabetta Conci, Maria Pia Dal Canton, Maria Badaloni, Ida d'Este, Vittoria Titomanlio, et al. "Disposizioni sulla stampa destinata all'infanzia e all'adolescenza." 17 December 1955. Camera dei deputati: Portale Storico. Parlamento Italiano, n.d. http:// storia.camera.it/documenti/progetti-legge/19551217-1964-savio-ed-altri-disposizionisulla (26 April 2018).

4 An early version of this article was published as Piepoli (2010). The present revision includes further exploration and an extended bibliography, as well as additional checks on the works and events mentioned throughout the text. 
Tuveri, Igor. "il fattore k." Black 2 (2001): 8-9.

Wertham, Fredric. Seduction of the Innocent. New York: Rinehart, 1954.

Wolk, Douglas. "R.I.P.: The Comics Code Authority." TIME.com. 24 January 2011. http:// techland.time.com/2011/01/24/r-i-p-the-comics-code-authority/ (26 April 2018).

Dr Angelo Piepoli received his $\mathrm{PhD}$ in Information and Communication Theory from the University of Macerata in 2007. He is a scholar of semiotic textology and the history and techniques of comics. He acted as a research collaborator at the former Department of Social Change, Legal Institutions, and Communication, and as a teaching assistant for courses in semiotics and applied semiotics at the former Faculty of Communication, at the University of Macerata, where he collaborated with the linguist and semiotician János Sándor Petöfi. He has published various contributions on comics studies in journals such as Heteroglossia and IJOCA, as well as in volumes such as Il '68 Diffuso, Prospettive di Semiotica del Testo, and Imaginaire et Idéologie du Plurilinguisme Littéraire et Numérique. He acted as editor-in-chief, programme director, and writer at Radio Università di Macerata, where he presented Splash Page!, a radio programme on comic art and publishing. He is a founding member of the ICLA Research Committee on Comics Studies and Graphic Narrative. 